\title{
Closure of German Hard Coal Mines: Effects and Legal Aspects of Mine Flooding
}

\author{
Marion Stemke ${ }^{1} \cdot$ Georg Wieber $^{1}$
}

Received: 1 February 2021 / Accepted: 19 November 2021 / Published online: 18 December 2021

(c) The Author(s) 2021

\begin{abstract}
Following the closure of the last hard coal mines in Germany, pumping is no longer necessary. However, the resulting rise of mine water can affect the environment. Laws have been enacted at the European and national level to protect properties. Within the framework of the approval procedure, it must be determined whether the cessation of pumping may cause unacceptable effects, including water pollution. With regard to water protection, the European Union has issued the Water Framework and Groundwater Directives, which have been implemented into German national law. These contain the prohibition of deterioration and the requirement for improvement, with the aim of maintaining or achieving good ecological and chemical status. However, before the target mine water level is reached, the water does not need to comply, since although the pumps are switched off, no mine water is being discharged. This also rules out permit requirements, which only go into effect when the target mine water level has been reached and mine water is discharging. Obviously, however, detailed planning before then is necessary.
\end{abstract}

Keywords Legislation $\cdot$ Mine water $\cdot$ Mine water discharge $\cdot$ Environmental quality standard

\section{Introduction}

Most developed countries have established detailed requirements and procedures for mine closure, though some countries have few or no applicable laws, regulations, standards, or norms (Blommerde et al. 2015). In Australia, for example, individual states and territories are responsible for mining, rehabilitation, and mine closure, including the adoption of individual laws, regulations, and guidelines. Industry and government agencies have established policies, principles, and guidelines for mine closure (Morrison-Saunders et al. 2016) and the country has enacted legislation with mine closure requirements. However, the legislation is not written as stand-alone laws. For example, laws on mine closure are either enacted as part of the mining sector or through specific environmental laws that apply to the mining sector (Kabir et al. 2005). This includes the Environment Protection and Biodiversity Conservation Act (EPBC 1999), which provides a uniform national framework for the environmental

Marion Stemke

mstemke@uni-mainz.de

1 Johannes Gutenberg-University, 55099 Mainz, Germany impact assessment of new projects and modifications. If a project has a substantial environmental impact, it is referred to Australia's EPA for review. The largest share of control of the mining industry belongs to the Ministry of Minerals and Energy (Morrison-Saunders et al. 2016).

In the Federal Republic of Germany, the last hard coal mines (Fig. 1) were closed in 2012 (Saarland) and 2018 (Ruhr area and Ibbenbüren), which eliminated the need for dewatering. Until the $1950 \mathrm{~s}$, the flooding of mines in Germany usually took place without planning or consideration of extensive environmental damage (Kroll et al. 2005). Since then, numerous laws, ordinances, and regulations have been enacted to protect the environment.

The paper is intended to explain the German legal situation and its interpretation with regard to potential environmental impacts caused by mine flooding. In the last three mining districts is the Ruhr area (Fig. 1), the surface has subsided by more than $25 \mathrm{~m}$ (Harnischmacher et al. 2010). To cope with the eternal burdens of coal mining, a "Erblastenvertrag" (legacy agreement) was concluded in 2007 between the RAG Foundation and the federal states of North RhineWestphalia and Saarland. In this agreement, the long-term liabilities of the mining industry are described in a report (KPMG 2006) as: (a) measures of mine water management; 


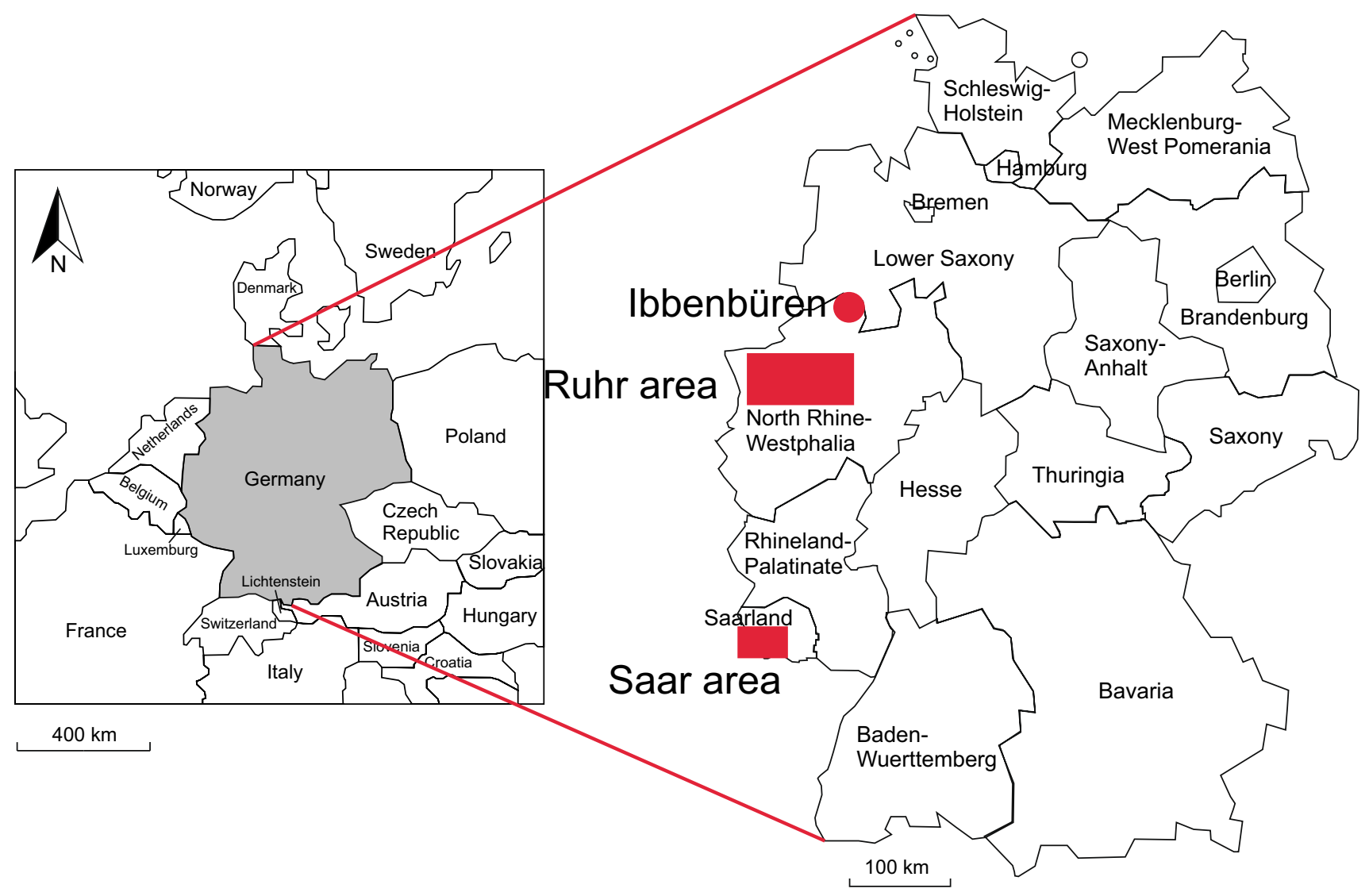

Fig. 1 Location of the last German hard coal mines

(b) groundwater treatment measures at contaminated sites; and (c) measures particularly pertaining to low-lying land (polder), to manage, deal with, and/or remediate permanent mining damage due to subsidence.

Coal mining and associated pumping substantially changed geological and hydrogeological conditions to depths $>1600 \mathrm{~m}$ and lowered the groundwater table below the working faces. The adits and shafts cross the predominantly low-permeability Carboniferous rock, allowing high flow velocities across geological barriers. The seepage and groundwater that flowed into (or would have flowed into) the mine workings was discharged into the surrounding water bodies (e.g. rivers). In addition, mining loosened the rock and caused subsidence (Li et al. 2018; Marts et al. 2014).

After closure, there is no need for further dewatering of the mines. Therefore, the water level rises in the abandoned mine workings. In some mining areas, particularly in the Ruhr area, this process could affect natural and constructed areas (Fig. 2).

As a result of coal mining and the associated lowering of ground water levels, the Ruhr area, in contrast to the mountainous regions of Saarland and Ibbenbüren, has locally subsided by more than $25 \mathrm{~m}$ (Harnischmacher 2010). The resulting depressions (polder areas) must be permanently drained to counteract large-scale water impoundment (no. 1 in Fig. 2) at the surface. The subsidence has also led locally to changes in the gradient, up to and including a reversal of the flow direction of streams due to the change in terrain. In this case, pumps at the deepest point of the watercourse ensure that the original direction of water flow is maintained. On larger watercourses, it may also be necessary to raise dikes to protect against flooding. Regulation of ground water levels in polder areas are long-term liabilities. If all polder pumps were switched off, the Ruhr area, with an area of $\approx 4450 \mathrm{~km}^{2}$, would be largely flooded, with $\approx 5.3$ million inhabitants affected.

Mine water flooding could reverse the previous subsidence processes in some places, resulting in uplift, but to a lesser extent (no. 2 in Fig. 2). Uplifts could be observed in the Wittener Mulde, the South Limburg mining area, as well as in Erkelenz and Aachen. Uplift is caused by two different processes: expansion processes that occur during flooding in the loosened carboniferous rock and due to pore pressure changes in the overlying overburden. So far, uplift attributed to mine flooding has been in the range of 0.2 to $0.3 \mathrm{~m}$, which corresponds to an average of $0.3 \%$ of mining-related subsidence (Rosner et al. 2014; Vervoort and Declercq 2018). 


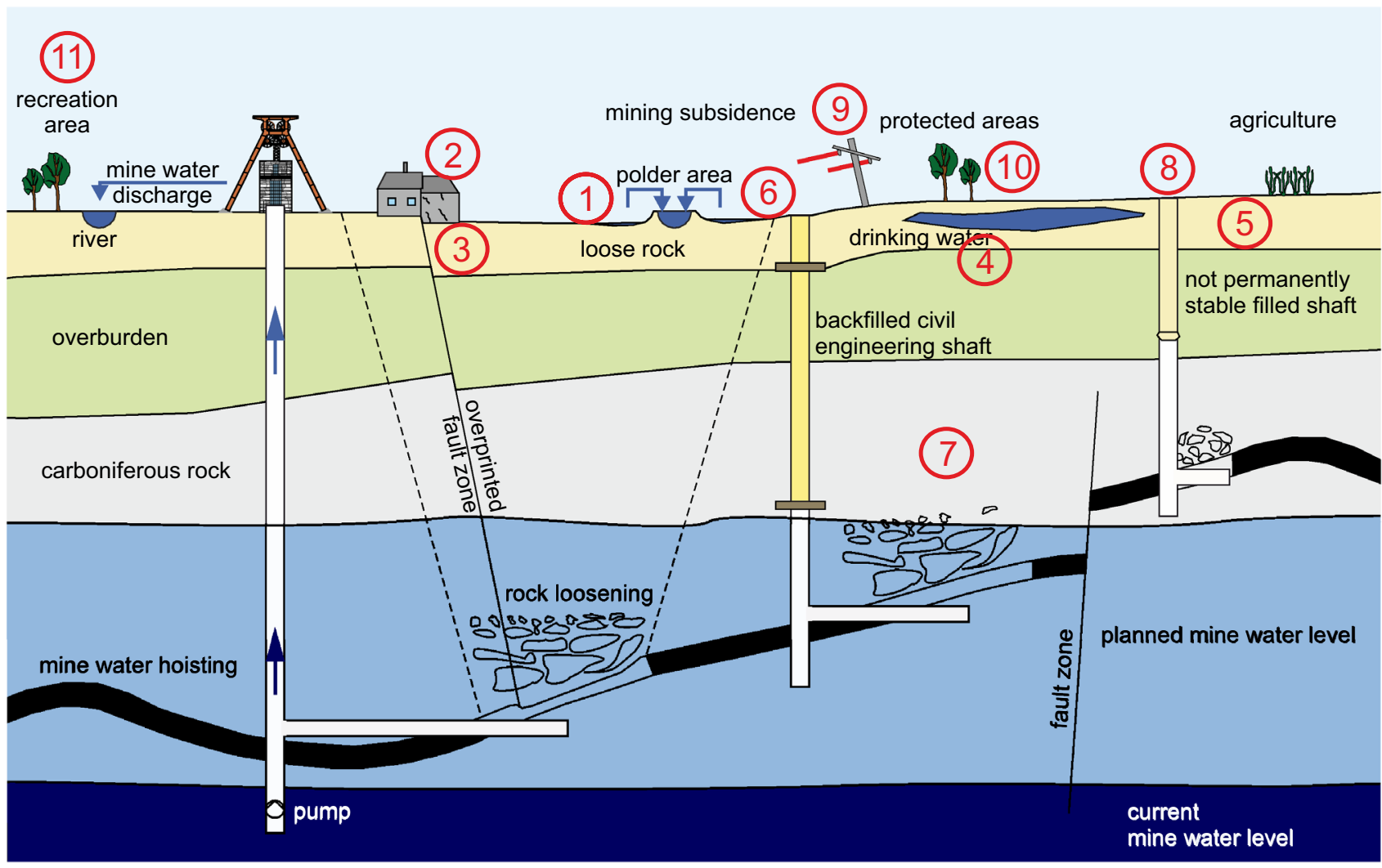

1 polder measures

2 uplift and subsidence

3 methane and radon emissions

4 drinking water protection

5 soil protection

6 surface water protection

7 geological processes (seismicity)

8 shaft protection

9 influences on protected goods

10 flora and fauna habitats (FFH)

11 emission and immission

Fig. 2 Illustration of possible effects of mining

High concentrations of methane (no. 3 in Fig. 2) and geogenic radon occur in mine workings. These gasses could be emitted by the rebounding mine water along fault zones that intersect the surface. However, no increase of outgassing was shown during previous mine water rises (Melchers et al. 2014).

Further effects depend on the mine water level. In the case of a high-water level, the risk of impairments to the upper (used) aquifers, drinking water protection areas (no. 4), and soils (no. 5) cannot be excluded. The rising, deep groundwater is mostly anaerobic, often highly mineralised, and may have elevated barium concentration and other geogenic accumulations of potentially problematic substances. During mine flooding, efflorescent salts formed in the aerobic environment dissolve, which can (temporarily) change the mine water chemistry (Sengupta 1995).

Due to the rising mine water level, rock stresses can occur from pore pressure increases. If these are suddenly discharged, micro-earthquakes (no. 7) can occur. Previous calculations and experience show that the magnitude of flooding-induced seismic events are considerably less than those that sometimes occur during mining. For example, the probability that only magnitudes up to 3.2 (Richter scale) 
will occur during flooding of the Saar mines was determined to be $99.9 \%$ (Alber 2016, 2020).

Possible effects on mine shafts and openings must also be considered. Current mine closure practices secure shafts (no. 8) with cohesive filling columns. Prior to the mid-1970 s, shafts were (partially) backfilled with uncompacted loose material. There were also no standards or binding specifications for covering the shafts during this period. These columns can become wet as the groundwater rises, which could trigger mass movements. If this scenario occurs, the shaft cover at the shaft head could fail, leading to subsidence or sinkhole funnels at the surface (Bekendam et al. 1995; Preuße et al. 2007).

The potentially problematic aspects described so far require special attention and must be checked for harmlessness in accordance with applicable legal requirements. However, the positive effects that can occur during mine flooding must also be mentioned.

As explained above, the discharge of mine water can affect the biological and chemical quality of surface water (no. 6). During flooding, the mine water increasingly receives low mineralised water; as a result, the overall mineralisation of the mine water and the load on rivers from the discharge can decrease. The closure of dewatering systems can relieve rivers over a length of $\approx 240 \mathrm{~km}$. These include, in particular, the Emscher and tributaries of the Saar (RAG AG 2016).

Mine flooding is legally permissible only up to the level at which adverse effects on the protected assets can largely be ruled out (minor negative effects are permissible provided that proportionality is observed). The objects to be protected are: (1) people, in particular human health; (2) animals, plants and biodiversity (no. 10); (3) area, soil, water, air, climate and landscape; (4) cultural heritage and other material assets; and (5) the interaction between the abovementioned objects of protection.

Pumping of mine water is energy-intensive and therefore causes high $\mathrm{CO}_{2}$ emissions (no. 11). Closure means that it is no longer necessary to lower the groundwater table to such great depths, which reduces adverse environmental impacts and lower costs.

\section{Legal Framework}

The legal framework for mine water collection and discharge comprises European, national, and state-specific legislation (Fig. 3). European legislation is adopted by the European Parliament and Council in the form of directives. These include, among others, Directive 2000/60/EC “establishing a framework for Community action in the field of water policy", also known as the Water Framework Directive or WFD, Directive 2006/118/EC "on the protection of groundwater against pollution and deterioration" (Groundwater Directive or GD), and Directive 2008/105/EC "on environmental quality standards in the field of water policy" (Environmental Quality Standards Directive or EQS), which sets the environmental quality standard for priority substances and certain other pollutants. The European Directives have been implemented into German national law: the Wasserhaushaltsgesetz (WHG), the Grundwasserverordnung (GrwV), and the Oberflächengewässerverordnung (OGewV: Surface Water Ordinance). The federal German states have in turn implemented them into state laws and are responsible for the permits and their monitoring.

\section{General Information}

The term mine water is used herein to describe "all water that is or was in contact with underground and open-cast mines" (Burghardt et al. 2017). It is a mixture of groundwater, formation water, seepage water, and process water, which flows into the mine workings and collects there. Depending on its origin and composition, the mine water corresponds to the natural groundwater quality, but may also contain impurities. Regionally, for example in the Ruhr area, high-saline mine water occurs with a proportion of ascending deep water. Likewise, mine water may contain anthropogenic contamination, such as the hydraulic fluids (PCBs) used in mining.

In Germany, mine water is not legally defined as wastewater (Wolkersdorfer 2005) if it is not altered by human use before it is discharged into other water. Nor does mine water become wastewater if it is contaminated with dissolved salts or non-organic substances that were dissolved during infiltration from natural rock (ERMITE 2004; Vogt 2020). The legal bases for these statements are based on European, country-specific, and regional legislation, with European legislation being transposed into national law.

Mine drainage is part of the operational planning process in active coal mining. Not only the construction and operation, but also the decommissioning by means of a final operating plan must comply with the Bundesberggesetz (BBergG: Federal Mining Act). The operating plan is subject to licensing if no effects harmful to the community are to be expected. According to decisions of the Federal Administrative Court and Higher Administrative Court (BVerwG 1995 and 2014; OVG Münster 2012), this also includes issues of water pollution control. As part of the approval procedure, it must be determined that harmful effects, including water pollution, can be ruled out if mine water management is discontinued (Jordan et al. 2017).

In addition to the approval of the operational plan, permits are required for both water use and discharge and the achievement of good ecological and chemical status of water 
Fig. 3 Legal framework

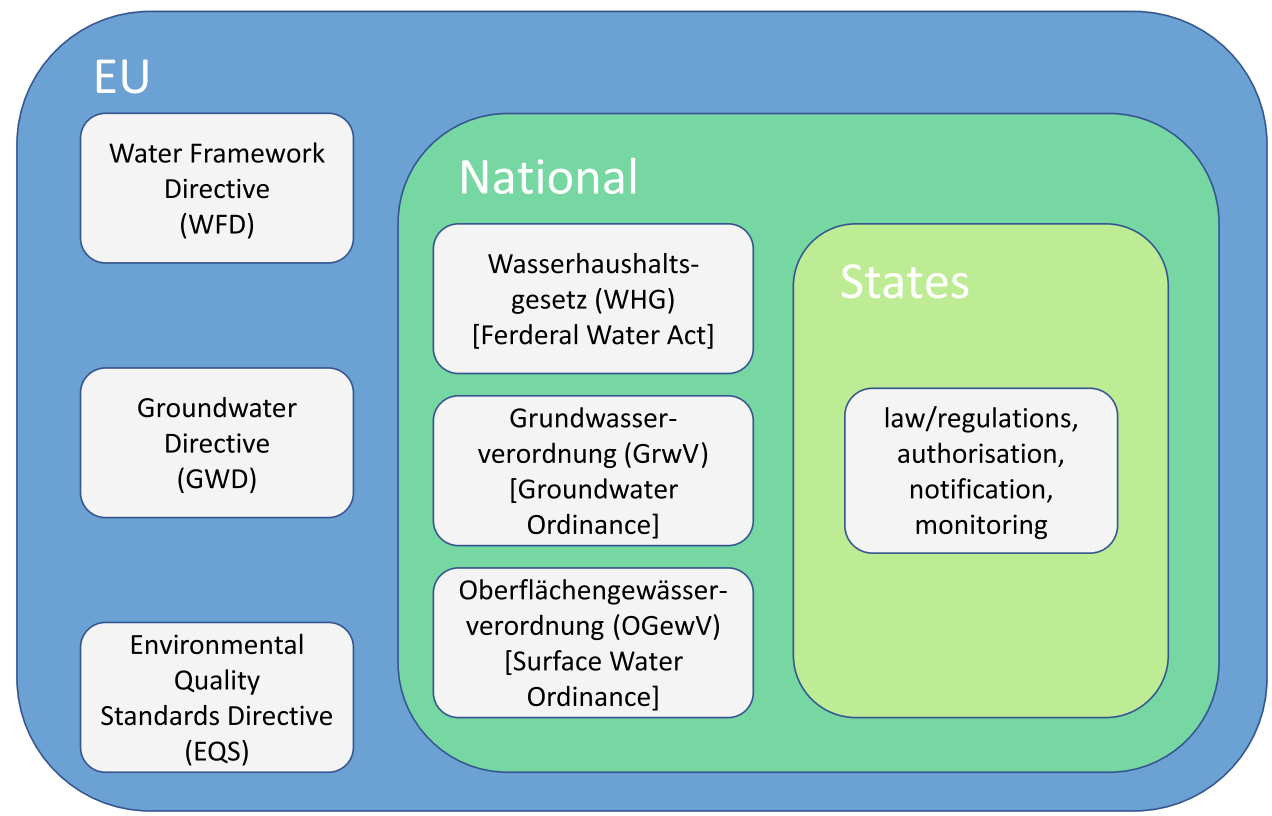

bodies should be a management objective. Deviations from these objectives are only permitted if "the water are so adversely affected by human activities or their natural conditions are such that achievement of the objectives is impossible or would entail disproportionate effort" (Wieber 2013).

The WHG distinguishes between two types of use, genuine and non-genuine use of water bodies. In the case of genuine use, a water body is subject to direct influence, whereas non-genuine use includes measures that do not constitute direct use, but may have an impact on the water body.

Mine water pumping and discharging constitutes use and requires a permit, as does "impounding, lowering, and diverting of groundwater" and measures that are likely to cause permanent or considerable adverse changes in water quality. The pumping and discharge of mine water should be part of the operating plan submitted for approval by the mining authority (Jordan et al. 2017; Wieber 2013).

Harmful soil changes caused by polluted mine water are also prohibited by the Bundesbodenschutzgesetz (BBodSchG: Federal Soil Protection Act). This is the case if there are impairments of soil functions that cause hazards, or considerable disadvantages or nuisances for individuals or the general public (Wieber 2013).

\section{Mining Law}

Construction and operation as well as the discontinuation of mining operations all require appropriate approval. The BBergG stipulates that exploration and extraction operations and processing plants may only be established, managed, and closed if the operator draws up operating plans and these have been approved by the responsible authority. This means that the cessation of mine dewatering is subject to approval under the mining law. Approval of a business plan should be granted if no harmful effects on the community are to be expected, but the final operating plan for the discontinuation of an operation must also contain proof that the requirements specified in the law are fulfilled. According to the case law of the BVerwG (Federal Administrative Court), issues of water pollution must also be clarified in the context of the mining. This means that in the case of discontinuation of mine water management, the approval procedure must include whether harmful effects on the community, such as water pollution, are to be expected (Wissenschaftlicher Dienst 2018).

Jordan et al. (2017) state that the licensing requirements of the WHG also apply to water-legal uses of mining operations, so that water-legal permits are required in addition to operational plan permits. The mining authority is responsible for issuing a permit or authorisation under water law if the use is provided for in an operating plan. The mining authority decides on the use of water rights in agreement with the competent water authority. This means that no permit is possible without the agreement of the water authority.

\section{Environmental Impact Assessment}

Mining companies are initially subject to the provisions of the Ordinance on the Environmental Impact Assessment of Mining Projects (UVP-V Bergbau). This distinguishes between a basic environmental impact assessment and an initially general or site-related preliminary assessment. The 
preliminary examination has two results: (1) a decision must be made whether a project may cause considerable environmental damage and whether an environmental impact assessment is therefore required; (2) this decision then affects the nature of the authorisation procedure. If an environmental impact assessment is required, a planning approval procedure with public participation must be carried out. If no environmental impact assessment is required, the decision is taken without public participation, though the result of the preliminary examination must be made known to the public.

One of the criteria for assessment is whether a project may have considerable impacts on human beings, animals, plants, biological diversity, surface area, soil, water, air, climate, landscape, cultural heritage and other material assets, as well as the interaction between the aforementioned objects of protection. When specifying in which respects the objects of protection may be affected by the project, the effects listed in Table 1 in particular must be considered. In addition, the extent to which a project may have considerable negative environmental effects must be considered. Classification is made according to Annex 3 No. 3 UVPG (from: BLAK UVP 2004; UBA 2006) (Table 2).

Table 1 Possible effect on protected property (UVPG Annex 4 No. 4b).
Table 2 Environmental impacts (UVPG Annex 3 No. 3).

Mining projects that are subject to an environmental impact assessment and to an operational plan are regulated in Environmental Impact Assessment of Mining Projects (UVP-V Bergbau). An environmental impact assessment is mandatory for underground mining if an area of 10 ha or more is required above ground or if subsidence of the surface of more than $3 \mathrm{~m}$ is to be expected. If relevant impairments are to be expected with regard to receiving water, groundwater, soils, protected cultural assets or comparable protected assets, an environmental impact assessment is mandatory even if the surface is only lowered 1 to $3 \mathrm{~m}$. However, the cessation of mine dewatering to achieve a predefined target horizon and subsequent resumption and discharge into a surface water body is not part of the UVP-V Bergbau (Jordan et al. 2017).

As part of the planned mine water flooding process, an environmental impact assessment is mandatory for mine water discharge volumes of 30 million $\mathrm{m}^{3} / \mathrm{a}$ or more, along with public participation. The relevant mining authorities are factually authorised and must issue the permit in agreement with the competent water authority (Vogt 2020).
Table 1 Possible effect on protected property (UVPG Annex 4 No. 4b)

\begin{tabular}{ll}
\hline Protected property & Type of effect \\
\hline People, in particular human health & Effect both on individuals and on the population \\
Animals, plants and biodiversity & Effects on flora and fauna \\
Soil & Changes in organic matter, soil erosion, soil compaction, soil sealing \\
Water & Hydromorphological changes, changes in quantity or quality of water \\
Climate & Climate changes, e.g. through greenhouse gas emissions, changes in \\
& the microclimate at the site \\
Material goods & Effect on infrastructure (roads, buildings, pipelines, etc.) \\
\hline
\end{tabular}

Table 2 Environmental impacts (UVPG Annex 3 No. 3)

\begin{tabular}{ll}
\hline Effects & Explanation \\
\hline Scale (territorial or population coverage) & $\begin{array}{l}\text { Spatially (in relation to protected goods); } \\
\text { population-related (e.g. residential areas) } \\
\text { Does not concern directly bordering countries either } \\
\text { Transboundary nature }\end{array}$ \\
$\begin{array}{l}\text { Is determined by quality or intensity } \\
\text { exceeding test values or falling below size or power values }\end{array}$ \\
If there are several environmental goods and interactions \\
Complexity & $\begin{array}{l}\text { Climate changes, e.g. through greenhouse gas emissions, changes in the microclimate at the site } \\
\text { Probability }\end{array}$ \\
Duration & $\begin{array}{l}\text { Limited to a certain period of time (e.g. construction phase) or } \\
\text { permant impairment }\end{array}$ \\
Frequency & $\begin{array}{l}\text { Frequency may be relevant to the severity of the environmental impact } \\
\text { If environmental impacts are restored to their original state through regeneration or natural suc- } \\
\text { Reversibility }\end{array}$ \\
\end{tabular}




\section{Surface Water}

The requirements of the WFD were implemented in Germany by the WHG (Fig. 2) (Plinke et al. 2003). The WFD aims to ensure a common European water policy within a "transparent, efficient and coherent legal framework". The aim of the Directive is to preserve and improve the aquatic environment, with the emphasis on water quality and quantity.

The WFD commits Member States to take all necessary measures to prevent deterioration in the status of all bodies of surface water and to protect, enhance, and restore them. The measures necessary to achieve this aim include progressively reducing pollution from priority substances and ceasing or phasing out discharges, emissions, and losses of hazardous substances. A body of surface water is in a good status if it has at least "good" ecological and chemical status, according to the EQS Directive.

The EU requirements were incorporated into the WHG as management objectives. Under the WHG, surface water not classified as artificial or heavily modified must be managed in such a way that both deterioration of their ecological and chemical status is avoided, and good status is maintained or achieved. Even for surface water classified as artificial or heavily modified, deterioration of their ecological potential and chemical status must be avoided. To this end, the requirements of the WFD and the EQS have been transposed into national law in the OGewV (Vogt 2020). The classification of ecological status or ecological potential is based on the biological quality. For rivers and lakes, the phytoplankton, macrophytes/phytobenthos, benthic invertebrate, and fish fauna components determine whether the water body is rated as "very good", "good", "moderate", "unsatisfactory" or "poor".

The same applies to deterioration in the chemical status of a surface water body. However, in contrast to ecological status, the classification is not based on this five-tier scale, but on a two-tier scale, as "good" or "not good". As soon as a project exceeds at least one of the environmental quality standards specified in the $\mathrm{OGewV}$, it is considered to have deteriorated. If a pollutant has exceeded the environmental quality standard in its current state, any further increase in pollutant concentration is not permitted (Vogt 2020). If it is not possible or disproportionate to achieve "good status", a trend reversal should be achieved.

With regard to the discharge of mine water, it is therefore necessary to assess whether there is a risk of deterioration in chemical and ecological status. If this is the case, technical mitigation measures are required to prevent deterioration of the aquatic environment. However, the BVerwG found that "the possibility of derogation permits a deterioration in both quantitative and chemical status as long as this is based on a change in physical water quality or groundwater level" (NuR 2020).

Consideration must also be given to the concerns of internationally concluded treaties such as the UNECE Water Convention, to which 46 states have now acceded (status 2021, www.unece.org/environment-policy/water/about-theconvention/status-ratification). The Water Convention serves the purpose of integrated water management in the region, in particular the protection of transboundary watercourses by preventing, controlling, and reducing transboundary pressures. It also aims at the appropriate and balanced use of water resources and the protection and restoration of ecosystems. The Water Convention contains general provisions on water management, monitoring, and research. It also lays down specific requirements for states that share water bodies or river basins. This includes, for example, the obligation to set up coordination bodies, to issue warnings in the event of accidents, or to inform themselves about the effects of planned projects (BMU/UBA 2017).

\section{Groundwater}

As with surface water, the WHG also regulates the management of groundwater, with three management objectives: (1) deterioration in quantitative and chemical status must be avoided; (2) all considerable and sustained upward trends in pollutant concentrations resulting from the effect of human activity must be reversed; and (3) good quantitative and chemical status must be maintained or achieved. Good quantitative status means that extraction is less than groundwater recharge.

The legal provisions are specified in more detail in the GrwV, where threshold values for the assessment of chemical groundwater status are listed These are usually based on a human and ecotoxicological assessment. In 2004 and 2015/2016, the Länder-Arbeitsgemeinschaft Wasser (LAWA), or State Working Group on Water established Geringfügigkeitsschwellenwerte (GFS: minor threshold values) for groundwater. These represent a yardstick on "the concentrations of substances up to which anthropogenic, spatially limited changes in the chemical composition of groundwater can be classified as minor". The background for GFS is the distinction between minor change and harmful contamination of groundwater chemical status. To define the GFS, LAWA has developed criteria, which largely correspond to those of the Federal Soil Protection Ordinance (BBodSchV). In addition, parameters relevant to contaminated sites or recycling were recorded insofar as a sufficiently large data set was available.

Foundation for the GFS's derivation is based on human and ecotoxicological effects, "a concentration at which, 
despite an increase in substance contents compared to regional background values, no relevant ecotoxicological effects can occur and the requirements of the Trinkwasserverordnung (TVO: Drinking Water Ordinance) or correspondingly derived values are met". The aim is to preserve groundwater for drinking water use and as a habitat.

Inorganic substances occur geogenically in groundwater. Trace elements are subject to dynamic processes and therefore vary in concentration. As a result, unaffected groundwater may have concentrations above the GFS and would thus be considered polluted water. For this reason, base values reflecting the groundwater quality in Germany are added to the ecotoxicologically derived values. The base value is represented as a surface-weighted average, shown as the 90th percentile value, which is then added to the ecological effect threshold (LAWA 2004).

The geogenic background value is defined as the concentration of a substance or a pollution indicator in a groundwater body that is not or only inconsiderably influenced by human activity. In the event that the threshold value specified in the GrwV for a substance or group of substances is less than the background level of the hydrogeochemical unit, the competent authority shall establish a different threshold value, taking into account the measured data.

\section{Mine Water Pumping and Dewatering}

For mines with active dewatering, mine water that is not in hydraulic contact with surface water has no ecological function. Due in particular to its depth and mineralisation, groundwater is considered less worthy of protection if it is geogenically impaired with pollutants or does not participate in the natural balance due to geological barriers (Vogt 2020).

When operating a mine dewatering system, the water is collected, pumped to the surface, treated, and discharged into a receiving water courses. Extraction of the mine water constitutes a use according to the WHG. Thus, in addition to the approval by a mining law operating plan, a water law permit is required (Wissenschaftlicher Dienst 2018). In addition, the injection and discharge of mine water into the groundwater requires a permit, which is granted only if there is no reason to fear an adverse change in water quality. A concern exists if there is a possibility of damage occurring that can be predicted based on a concrete and comprehensible determination. Relative to the constitutional principle of proportionality, the different worthiness of protection of the groundwater resource as well as the probability and magnitude of the risk of contamination must be considered (Vogt 2020).

The cessation of mine drainage in the German mining regions is planned in partial steps. For example, flooding from -600 to $-320 \mathrm{~m}$ (relative to mean sea level) is planned for the Saarland in the first phase and has been applied for and permitted by the responsible authorities. The mine water level will then still be around $500 \mathrm{~m}$ below the surface, at a great distance from the drinking water and groundwater horizons. In the second phase, pumping could be completely stopped, which would allow a uniform mine water level to form in the entire Saar district and discharge freely into the receiving water courses. Phase 2 , however, requires a separate application and procedure before a permit can be issued for this step. Until the target mine water level is reached, there is no water utilization. As the pumps are switched off during this period, the mine water is not pumped and discharged. As a result, the characteristics of excavation and discharge within the meaning of the WHG are not fulfilled. This also precludes the need of water bodies to have a permit (Jordan et al. 2017).

With regard to the mining law-based operating plan approval procedure, it has to be determined which requirements have to be met by the mine operator for the cessation of pumping. This may also include an interdiction on the cessation of pumping (Jordan et al. 2017).

Unauthorised water pollution or the detrimental alteration of the characteristics of the water body is a punishable offence. According to the German criminal code: "anyone who pollutes a water body without authorisation or otherwise adversely alters its properties shall be punished with imprisonment for up to five years or a fine". Attempting to do so is also punishable. In the case of negligent acts, the offence may be punished with a prison sentence of up to three years or a fine (Wissenschaftlicher Dienst 2018). Water pollution is unauthorised if it is not covered by regulatory licence.

According to the BBergG, approval of an operating plan must be granted if no harmful effects to the public are to be expected. In the opinion of the Federal Administrative Court (BVerwG, judgment of 9 Nov. 1995), issues of water pollution must also be clarified in this context. Thus, the mining law operating plan constitutes a permit, whereby water pollution can be authorised (Wissenschaftlicher Dienst 2018).

\section{Conclusions and Recommendations for Action}

The first mining laws date back to medieval (12th - 13th century) times. These also regulated water use, but not yet from an environmental perspective. Greater environmental damage accompanied increased mining during industrialisation, which led to more stringent laws and regulations for environmental protection over time. These regulations, which have since been repealed, supplemented, or changed in their meaning, often continue to apply for a certain transitional period. This is because the new law often does not apply to 
legal relationships that were established before its entry into force or to facts that predate its entry into force. The old law must then continue to be applied in practice, sometimes for years. Therefore, the closure of mines must partly be carried out according to older legislation. Nevertheless, to enable an environmentally sound solution, legacy agreements should be concluded between the federal states and the operator.

Numerous processes are set in motion when the mine water level rises. These range from legal issues relating to environmental and water protection through the hoisting and discharge of sometimes highly mineralised mine water to surface movements and outgassing. International, national, and state-specific agreements, laws, regulations, and guidelines have been issued to minimise adverse effects on people and the environment. To ensure water protection, the European Water Framework Directive was adopted and implemented into German national law (WHG, GrwV). In addition to approval of an operational plan under mining law, water law permits are also required.

Continuous monitoring of both the mine water hoisting and the water quality and quantity of the receiving water must be ensured to identify potential water deterioration. Time series analysis can detect changes in relevant pollutants at an early stage and, if necessary, deterioration can be counteracted by treatment measures. Furthermore, background values of groundwater must be determined and geogenic pollutant anomalies detected, depending on geology and depth.

The cessation of mine dewatering in closed mines poses great challenges. This applies not only to the companies but also to the planning and licensing authorities. The entire process involves mining, environmental, and administrative procedural laws, and is accompanied by intensive public participation. In the final operating plan, the closure of the mines must be described in terms of licensing. Furthermore, the laws, ordinances, and guidelines are continuously being developed and adapted to ensure and improve protection of groundwater and rivers. Overall, this is a lengthy process, especially when intensive public participation is required. However, this procedure allows the interests of all groups involved to be considered and all assets to be protected during and after mine flooding.

In conclusion, the German Federal Mining Act is well suited for the implementation of these complex procedures. In particular, water law concerns and water protection requirements are sufficiently considered, as agreement must be reached with the responsible water authority. Approval without their consent is not legally permissible.

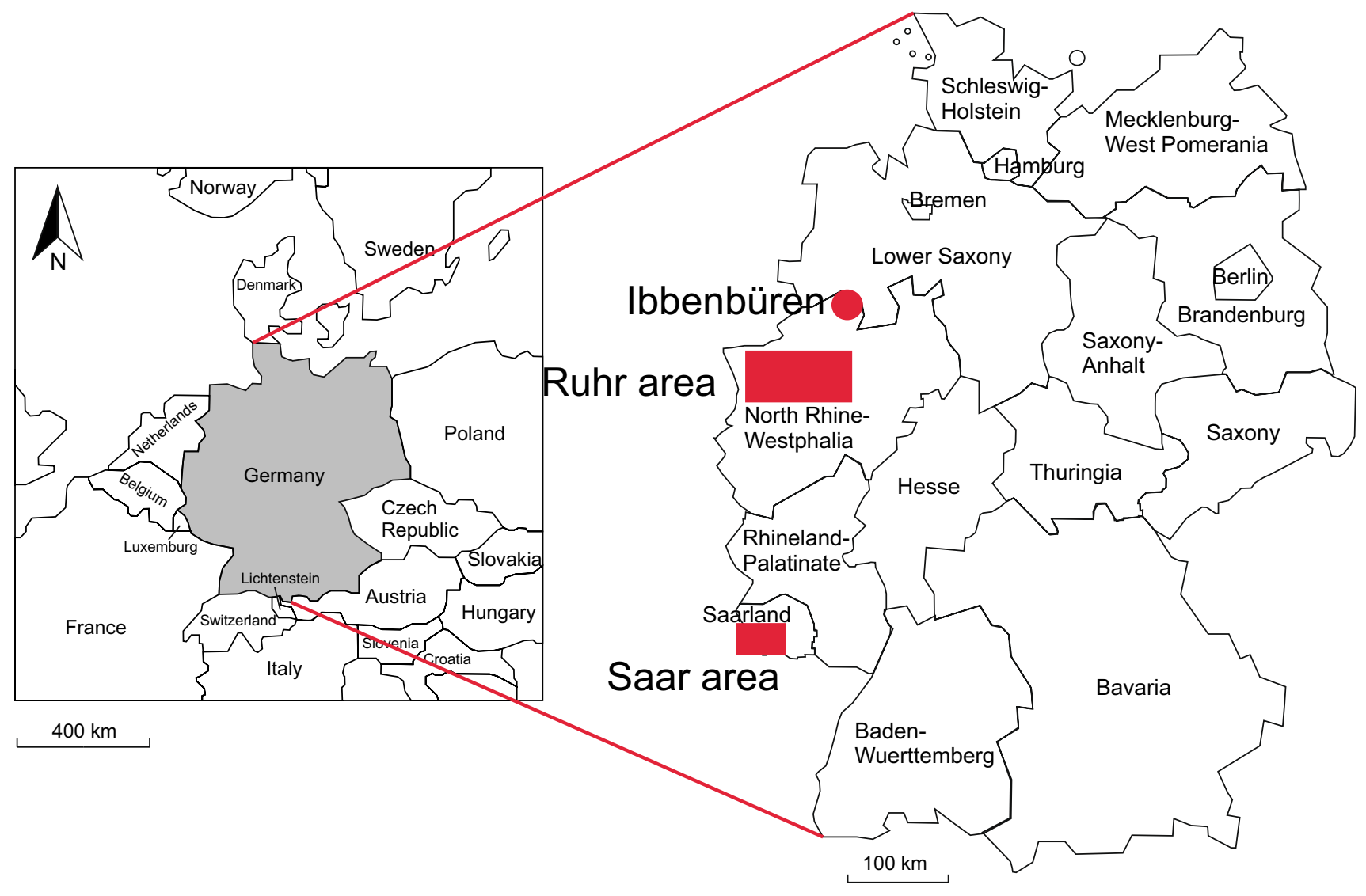




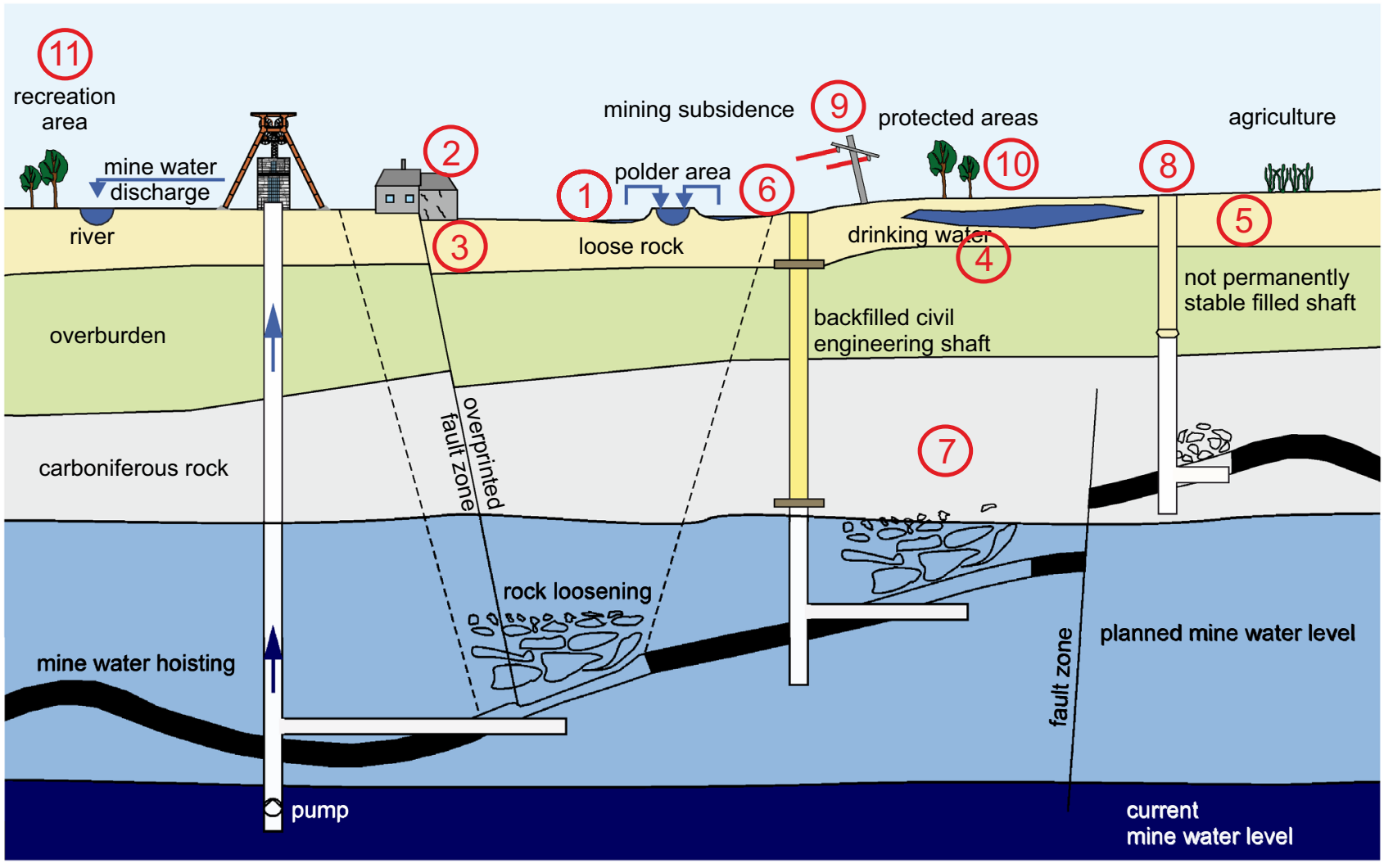

1 polder measures

2 uplift and subsidence

3 methane and radon emissions

4 drinking water protection

5 soil protection

6 surface water protection

7 geological processes (seismicity)

8 shaft protection

9 influences on protected goods

10 flora and fauna habitats (FFH)

11 emission and immission 


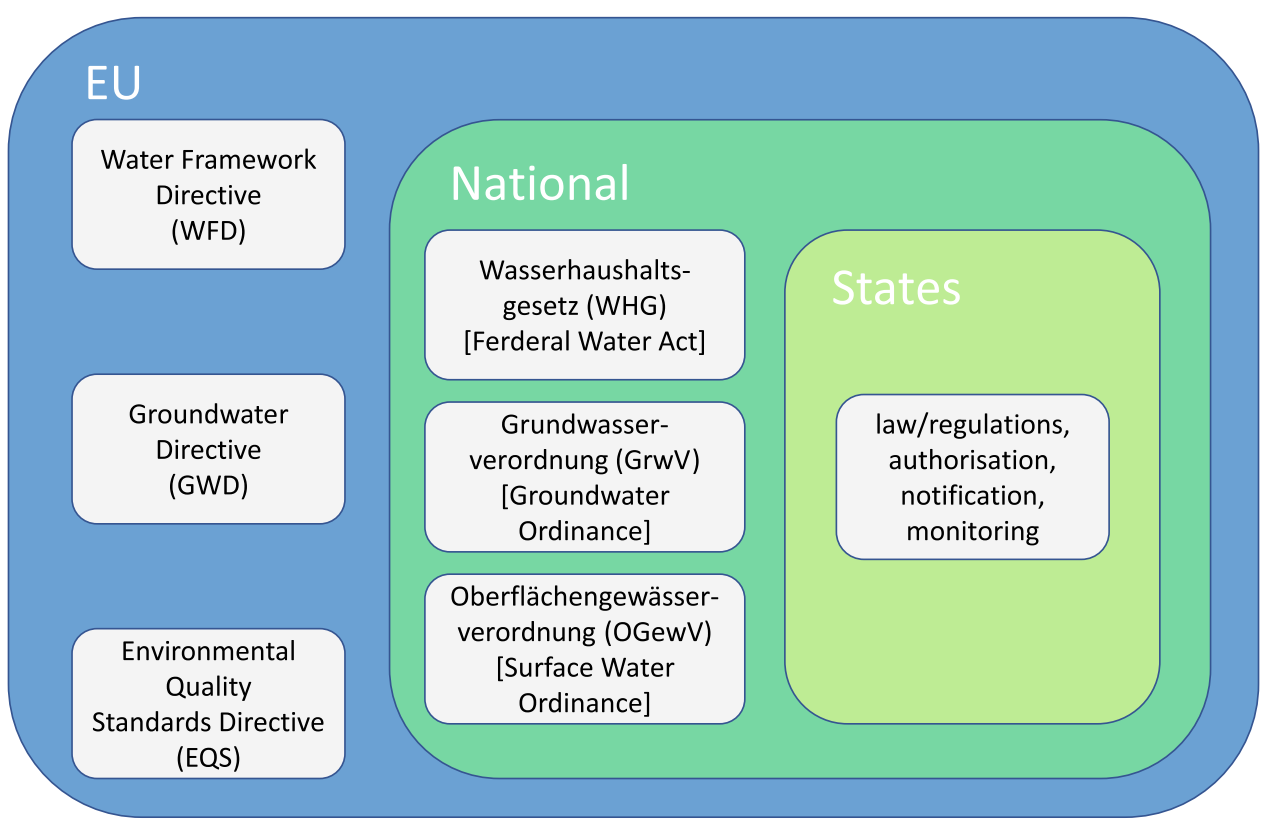

Acknowledgements The authors thank the editors and anonymous reviewers for their time, interest, and effort to evaluate our manuscript as well as for their thoughtful suggestions. This work was made possible within the framework of the "Forum Bergbau Wasser" Foundation, which we hereby thank for the support provided.

Funding Open Access funding enabled and organized by Projekt DEAL.

Open Access This article is licensed under a Creative Commons Attribution 4.0 International License, which permits use, sharing, adaptation, distribution and reproduction in any medium or format, as long as you give appropriate credit to the original author(s) and the source, provide a link to the Creative Commons licence, and indicate if changes were made. The images or other third party material in this article are included in the article's Creative Commons licence, unless indicated otherwise in a credit line to the material. If material is not included in the article's Creative Commons licence and your intended use is not permitted by statutory regulation or exceeds the permitted use, you will need to obtain permission directly from the copyright holder. To view a copy of this licence, visit http://creativecommons.org/licenses/by/4.0/.

\section{References}

Act EPBC, Act OPGGS (1999) Environment protection and biodiversity conservation act 1999. Canberra: comlaw. gov. au

Alber M, Backers T, Fritschen R, Neuffer T (2020) Remote seismic events induced by mine flooding. In: Li CC, Ødegaard H, Høien AH, Macias J (Eds.), Proc, ISRM International Symp Eurock

Alber M (2016) Gutachten zu Erschütterungen während des Grubenwasseranstiegs im Bergwerk Saar, Abbaufeld Primsmulde. http:// www.bid.rag.de. Accessed 18 Apr 2019 (in German)

BBergG (1980) Bundesberggesetz vom 13. August 1980 (BGBl. I S. 1310), das durch Artikel 2 Absatz 4 des Gesetzes vom 20.Juli 2017 (BGB1. I S. 2808) geändert worden ist (in German)
BBodSchG (1998) Bundes-Bodenschutzgesetz vom 17. März 1998 (BGB1. I S. 502), das zuletzt durch Artikel 3 Absatz 3 der Verordnung vom 27. Sept 2017 (BGB1. I S. 3465) geändert worden ist (in German)

BBodSchV (1999) Bundes-Bodenschutz- und Altlastenverordnung vom 12. Juli 1999 (BGBl. I S. 1554), die zuletzt durch Artikel 3 Absatz 4 der Verordnung vom 27. Sept 2017 (BGB1. I S. 3465) geändert worden ist (in German)

Bekendam RF, Pöttgens JJ (1995) Ground movements over the coal mines in southern Limburg, the Netherlands and their relation to rising mine waters. In: Johnson AI (Ed), Proc, 5th International Symp on Land Subsidence (FISOLS'95), Balkema, Rotterdam, pp 3-12

Blommerde M, Taplin R, Raval S (2015) Assessment of rehabilitation completion criteria for mine closure evaluation. Proc, 7 th International Conf on Sustainable Development in the Minerals Industry, Sustainable Development Indicators in the Minerals Industry (SDIMI), pp 13-15

BMU/UBA (Eds) (2018) Water Resource Management in Germany. Fundamentals, pressures, measures. Dessau-Roßlau. www.uba.de/ en/water-resource-management. Accessed 11 June 2021

Burghardt D, Coldewey WG, Melchers C, Meßer J, Paul M, Walter T, Wesche D, Westermann S, Wieber G, Wisotzky F, Wolkersdorfer C (2017) Glossar Bergmännische Wasserwirtschaft. Fachsektion Hydrogeologie in der DGGV, Neustadt/Wstr. (in German)

BVerwG (1995) Urteil vom 9. Nov 1995 - 4 C 25/94, Juris Rn. 37 - Beseitigung von Sauerwasser im Erzbergwerk Rammelsberg/ Harz (in German)

BVerwG (2014) Urteil vom 18. Dec 2014 - 7 C 22/12, Juris, Rn. 24-27, $33=$ BVerwGE. 151:156-171. (in German)

Environmental Quality Standards Directive (EQS) (2013) Directive 2013/39/EC of the European Parliament and of the Council of 12 Aug 2013 amending Directives 2000/60/EC and 2008/105/EC as regards priority substances in the field of water policy

Consortium ERMITE, Younger PL, Wolkersdorfer C (2004) Mining impacts on the freshwater environment: technical and managerial guidelines for catchment scale management. Mine Water Environ 23(Supplement 1):S2-S80. https://doi.org/10.1007/ s10230-004-0028-0 
European Commission (2000) Directive 2000/60/EC of the European Parliament and of the Council of 23 Oct 2000 establishing a framework for Community action in the field of water policy. Off J Eur Communities L 372:1-72

Groundwater Directive (GWD) (2006) Directive 2006/118/EC of the European Parliament and of the Council of 12 Dec 2006. on the protection of groundwater against pollution and deterioration

GrwV (2010) Grundwasserverordnung vom 9. Nov 2010 (BGB1. I S. 1513), die zuletzt durch Artikel 1 der Verordnung vom 4. Mai 2017 (BGB1. I S. 1044) geändert worden ist (in German)

Harnischmacher S (2010) Quantification of mining subsidence in the Ruhr District (Germany). Geomorphol Relief Process Environ16(3):261-274

Jordan I, Welsing R (2017) Einstellung der Grubenwasserhaltung nach Beendigung der Steinkohlengewinnung - Wasserrechtliche Betrachtung, Zeitschrift für Wasserrecht (ZfW) 56/2017, Heft 3 (in German)

Jordan I, Welsing R (2017) Einstellung der Grubenwasserhaltung nach Beendigung der Steinkohlengewinnung - Bergrechtliche Betrachtung, Zeitschrift für Bergrecht (ZfB), 158/2017:231-248(in German)

Kabir SMZ, Rabbi F, Chowdhury MB, Akbar D (2015) A review of mine closure planning and practice in Canada and Australia. World Rev Bus Res 5(3):140-159

Kroll AM, Betlem G, Amezaga JM (2005) Mine Water Pollution and European Policies.UNESCO Technische Reihe13/03/03

KPMG (2006) Gutachten zur Bewertung der Stillsetzungskosten, Altund Ewigkeitslasten des Steinkohlebergbaus der RAG Aktiengesellschaft Essen. KPMG Deutsche Treuhand-Gesellschaft [unveröffentlicht]. (in German)

LAWA (Länderarbeitsgemeinschaft Wasser) (2004) Determination of insignificance thresholds for groundwater. Published by Working Group of the Federal States on Water Issues (Länderarbeitsgemeinschaft Wasser) under the chairmanship of the state of North Rhine-Westphalia https://www.lawa.de/documents/gfs-report_ 1552302508.pdf. Accessed 16 June 2021

LAWA (2015) Hydrogeochemische Hintergrundwerte im Grundwasser und ihre Bedeutung für die Wasserwirtschaft. Erarbeitet von der Ad-hoc-Kleingruppe "Hydrogeochemische Hintergrundwerte der Grundwässer” des Ständigen Ausschusses „Grundwasser und Wasserversorgung " der LAWA und der Ad-hoc-AG Hydrogeologie des BLA-GEO vom 28.11.2013 bis 31.07.2015. www.lawa.de/ documents/kg_sgd_lawa_hintergrundwerte_151001_1552302338. pdf. Accessed 05 Aug 2020 (in German)

LAWA (2016) Derivation of insignificant threshold values for the ground water. Updated and revised version 2016. Published by Länderarbeitsgemeinschaft Wasser (LAWA) Ministerium für Umwelt, Klima und Energiewirtschaft Baden-Württemberg, Stuttgart 2017. www.lawa.de/documents/gfs-bericht_en_2_15523 07510.pdf. Accessed 16 June 2021

Li H, Zhao B, Guo G, Zha J, Bi J (2018) The influence of an abandoned goaf on surface subsidence in an adjacent working coal face: a prediction method. Bull Eng Geol Environ (2018) 77:305-315 https://doi.org/10.1007/s10064-016-0944-9

Marts JA, Gilmore RC, Brune JF, Bogin GE, Grubb JW, Saki S (2014) Dynamic gob response and reservoir properties for active longwall coal mines. Min Eng (2014) 66 (12):59-66

Melchers C, Dogan T (2014) Studie zu erfolgten Grubenflutungen in Steinkohlenrevieren Deutschlands und Europas. 14. Altbergbaukolloquium, Gelsenkirchen 2014, Tagungsband S. 300-305 (in German)

Morrison-Saunders A, McHenry MP, Rita Sequeira A, Gorey P, Mtegha H, Doepel D (2016) Integrating mine closure planning with environmental impact assessment: challenges and opportunities drawn from African and Australian practice. Impact Assessment and Project Appraisal 34(2):117-128
NuR (2020) Ausnahme von den Bewirtschaftungszielen des Wasserhaushaltsgesetzes. NuR 42: 554-556 (2020). https://doi.org/10. 1007/s10357-020-3729-7 (in German)

OGewV (2016) Verordnung zum Schutz der Oberflächengewässer (Oberflächengewässerverordnung - OGewV), Oberflächengewässerverordnung vom 20. Juni 2016 (BGB1. I S. 1373) (in German)

OVG Münster (2012) Urteil vom 26. Jan 2012 - 11 A 2635/09, Gewerbearchiv 2012, $72 \mathrm{f}$. (in German)

Plinke M, Wildhagen E (2003) Mining and water in Germany - legal framework and technical aspects. In: Nel PJL (Ed), Proc, 8th International Mine Water Assoc Congress, pp 279-286

Preuße A, Krämer J, Sokra A (2007) ) Technische Abschätzung von Folgelasten des Steinkohlenbergbaus. Bergbau 12/2007, S.540 546(in German)

RAG AG (2016) Schwerpunkt Wasser: Das Grubenwasserkonzept der RAG. Glück auf. Eine Anzeigenbeilage der RAG in Kooperation mit Ihrer Tageszeitung vom 25. www.rag.de/fileadmin/PageFlipDokumente/Glueckauf_Oktober2016/index.html. Accessed 14 Nov 2018 (in German)

Rosner P, Heitfed M, Spreckels V, Vosen P (2014) Auswirkungen von Geländehebungen im Zuge des Grubenwasseranstiegs im Ruhrrevier. RuhrGeo Tag 2014 Tagungsband S.153-177 (in German)

TVO (2001) Verordnung über die Qualität von Wasser für den menschlichen Gebrauch, (Trinkwasserverordnung - TrinkwV 2001), Trinkwasserverordnung in der Fassung der Bekanntmachung vom 10. März 2016 (BGBl. I S. 459), die durch Artikel 2 des Gesetzes vom 17. Juli 2017 (BGBl. I S. 2615) geändert worden ist (in German)

UBA (2006) Kriterien, Grundsätze und Verfahren der Einzelfallprüfung bei der Umweltverträglichkeitsprüfung. Forschungsbericht 20213129 UBA-FB 000910. Umweltbundesamt (Hrsg.). (in German)

UVPG (2010) Gesetz über die Umweltverträglichkeitsprüfung in der Fassung der Bekanntmachung vom 24. Februar 2010 (BGB1. I S. 94), das zuletzt durch Artikel 2 des Gesetzes vom 8. Sept 2017 (BGB1. I S. 3370) geändert worden ist (in German)

Bergbau UVP-V (1990) Verordnung über die Umweltverträglichkeitsprüfung bergbaulicher Vorhaben vom 13. Juli 1990 (BGB1. I S. 1420), die durch Artikel 2 Absatz 24 des Gesetzes vom 20. Juli 2017 (BGB1. I S. 2808) geändert worden ist (in German)

Vervoort A, Declercq PY (2018) Upward surface movement above deep coal mines after closure and flooding of underground workings. Int J Min Sci Technol 28(1):53-59. https://doi.org/10.1016/j. ijmst.2017.11.008

Vogt M (2020) Machbarkeitsstudie Zentrale Wasserhaltung Lohberg. https://www.rag.de/machbarkeitsstudie-lohberg/. Accessed 15 Aug 2020 (in German)

WHG (2009) Wasserhaushaltsgesetz vom 31. Juli 2009 (BGB1. I S. 2585), das zuletzt durch Artikel 1 des Gesetzes vom 18. Juli 2017 (BGB1. I S. 2771) geändert worden ist (in German)

Wieber G (2013) Stillgelegte geflutete Erzbergwerke - schädliche Bodenveränderungen gemäß Bundes- Bodenschutzgesetz? altlasten spektrum 5/2013, S.201-209(in German)

Wissenschaftlicher Dienst (WD) (2018) Wasserrechtliche und strafrechtliche Fragen zur Grubenwasserhaltung. Sachstand WD 7-3000081/18 (C2018 Deutscher Bundestag. www.bundestag.de/resource/ blob/557604/a028894a0460517a9ad44566e46dea40/WD-7-08118-pdf-data.pdf. Accessed 17 Aug 2020 (in German)

Wolkersdorfer C (2005) Mine water management and the water framework directive. Proc, Congress Post-Mining, pp 1-8

Publisher's Note Springer Nature remains neutral with regard to jurisdictional claims in published maps and institutional affiliations. 